\title{
MICROHARDNESS OF THE ENAMEL EXPOSED TO WHITENING DENTIFRICES.
}

\section{ANÁLISE DA MICRODUREZA EM ESMALTE BOVINO EXPOSTO A DENTIFRÍCIOS CLAREADORES.}

\author{
Alex Mendez de Arruda** \\ André Luiz Fraga Briso** \\ Osmir Batista de Oliveira Júnior*** \\ Paulo Henrique dos Santos** \\ Simone Cristina Tosti****
}

\begin{abstract}
Introduction: The purpose of this study is to verify the effect of three different types of dentifrices on the superficial microhardness of bovine enamel. Methods: Forty-eight $4 \times 4 \mathrm{~mm}$ dental fragments were polished and randomly divided into 4 groups: Gl, conventional silica-based dentifrice; GIl, hydrogen peroxide-based dentifrice; GIII, carbamide peroxide-based dentifrice; and GIV, immersion in artificial saliva. After polished, the specimens received five indentations of $25 \mathrm{~g}$ static load, for 5 seconds. Subsequently, specimens from groups Gl, GII and GIII were immersed in solution containing dentifrice and distilled water, in weight proportion of 1:2, for 15 minutes daily. After this period, fragments were rinsed in tap water and stored in artificial saliva at $370 \mathrm{o}$. This procedure was repeated for 21 days and then a new analysis of the microhardness was performed. Results and conclusion: The results were submitted to ANOVA and Fisher's test at 5\%. It was concluded that all samples treated with dentifrices showed hardness decrease, being most pronounced in dentifrices containing peroxide. DESCRIPTORS: Dentifrices • Dental enamel • Peroxides.
\end{abstract}

\section{RESUMO}

Introdução: O objetivo deste estudo é verificar o efeito de dentifrícios à base de peróxido de carbamida, peróxido de hidrogênio e um convencional rico em sílica, na microdureza superficial do esmalte bovino. Métodos: Para tanto, 48 fragmentos dentais de 4 x 4mm foram polidos, realizada então a leitura inicial da microdureza, e divididos aleatoriamente em 4 grupos: GI - dentifrício convencional; Gll - dentifrício contendo peróxido de hidrogênio; GIII - dentifrício contendo peróxido de carbamida e GIV - imersão em saliva artificial. Após o polimento, os espécimes receberam 5 indentações de carga estática de 25 gramas, por 5s. Após essa fase, os espécimes dos grupos Gl, GIl e GIII foram imersos em suspensão contendo dentifrício e água destilada, na proporção de 1:2 em peso, durante 15 minutos diários. Decorrido este período, os fragmentos foram lavados com água corrente e armazenados em saliva artificial a 37oC. Esse tratamento foi repetido por 21 dias e, após esse período, foi realizada a análise final da microdureza. Resultados e conclusão: Os resultados foram submetidos aos testes estatísticos ANOVA e teste de Fisher a 5\%. Concluiu-se que todas as amostras tratadas com dentifrícios sofreram diminuição na dureza, sendo esta mais pronunciada nos dentifrícios contendo peróxido.

DESCRITORES: Dentifrícios • Esmalte dentário • Peróxidos.

\footnotetext{
* Aluno de Doutorado do Departamento de Odontologia Restauradora, Faculdade de Odontologia UNESP, Univ Estadual Paulista, Araraquara - SP, Brasil.

** Professor do Departamento de Odontologia Restauradora, Faculdade de Odontologia UNESP, Univ Estadual Paulista, Araçatuba - SP, Brasil.

*** Professor do Departamento de Odontologia Restauradora, Faculdade de Odontologia UNESP, Univ Estadual Paulista, Araraquara - SP, Brasil.

**** Aluna da Graduação da Faculdade de Odontologia UNESP, Univ Estadual Paulista, Araçatuba - SP, Brasil.
} 


\section{INTRODUCT I ON}

Dental aesthetics is a constant concern for both professionals and patients. For this reason, the presence of dental color changes, either extrinsic or intrinsic has motivated the development and improvement of microabrasion (Hegedus et al. ${ }^{1}, 1999$, Casals et al. ${ }^{2}, 2007$, Correa et al. $\left.{ }^{3}, 2007\right)$, as well as whitening techniques (Correa et al. ${ }^{3}, 2007$, Croll ${ }^{4}, 1992$, Gerlach et al. ${ }^{5}$, 2002, Haywood et al. $\left.{ }^{6}, 1994\right)$.

The aesthetic results using dental bleaching techniques allowed the development of new bleaching products, including toothpaste based on carbamide peroxide and hydrogen peroxide (Hegedus et al. ${ }^{1}$, 1999, Croll ${ }^{4}, 1992$, Gerlach et al. ${ }^{7}, 2002$, Crews et al. ${ }^{8}$, 1997) rich in polishing agents, seeking chemical and mechanical removal of dental staining (Sasaki et al. ${ }^{9}$, 2007, Haywood ${ }^{10}$, 1992).

It is worth highlighting that although certain dentifrices promote the proposed whitening (Howard ${ }^{11}, 1992$, Ernst et al. ${ }^{12}$, 1996, Garcia-Godoy et al. ${ }^{13}$, 2004), they may cause high levels of abrasion, roughness and dental weariness (White ${ }^{14}, 2001$, Mankodi et al. $\left.{ }^{15}, 1999\right)$. These effects are common because whitening dentifrices are easily accessed by patients, and may be used without appropriate instructions, follow-up or awareness of the professional.

The literature reports several initial unwanted effects that highly-concentrated bleaching agents cause to the enamel structure, suggesting demineralization and hardness decrease(Casals et al. ${ }^{2}, 2007$, Faraoni-Romano et al. $\left.{ }^{16}, 2007\right)$. Thus, the understanding of the microhardness of a dental structure exposed to any oxidizing agent is of fundamental importance to conduct even the most innocuous treatments and obtain the bleaching effect without affecting the dental integrity.

Therefore, this study analyzed the in vitro effect of carbamide-and hydrogen peroxide-based dentifrices and a conventional rich-in-silica dentifrice on the superficial microhardness of bovine enamel. The null hypothesis tested is that there is no hardness difference between enamels exposed to dentifrices containing carba- mide peroxide or hydrogen peroxide.

\section{MATERIAL AND METHODS}

Forty-eight recently-extracted healthy bovine incisives were used. After removal, the teeth were cleaned with periodontal curettes (Duflex Ltda. Rio de Janeiro, Rio de Janeiro, Brazil), polished with pumice and water using a Robinson bristle brush (KG Sorensen Ind. e Com. Ltda, Barueri, $\mathrm{SP}$, Brazil). The teeth were then stored in a $0.1 \%$ timol solution until use.

The roots and dental pulp remnants were removed using a metallographic cutter (Isomet 2000 - Buehler, Lake Bluff, Illinois, USA). Subsequently, the crowns were analyzed in stereomicroscope (Carl Zeiss Company - DSM-940 A, Oberkochen, Baden- Württemberg, Germany) and only that the ones showed no cracks or other structural defects were selected. Dental fragments measuring $4 \times 4 \mathrm{~mm}$ were embedded in an acrylic resin base using an embedding machine (PRE-30S, Arotec S.A. Indústria e Comercio Ltda, Cotia, São Paulo, Brazil). The specimens were flattened and polished using a rotation machine (Aropol E, Arotec S.A. Industria e Comércio Ltda, Cotia, São Paulo, Brazil) and sandpaper $\# 600, \# 800$ and $\# 1200$ granulation, for 2 minutes each. The finishing was done using felt disc and $1 \mu \mathrm{m}$ polishing diamond paste (Arotec S.A. Indústria e Comercio Ltda,Cotia, São Paulo, Brazil), for 5 minutes.

Subsequently, the specimens were randomly divided into four study groups $(n=12)$ and received the treatments presented in Table 1.

All samples were initially cleaned with distilled water in an ultrasonic cleaner (BRANSON 2210, Danbury, Connectcut, USA), submitted to initial microhardness measurements by means of a microhardness tester (HMV-2000 SHIMADZU, Columbia, Maryland, USA), and a Knoop indenter under a static load of $25 \mathrm{~g}$ applied for 5 seconds. Each specimen received 5 indentations each time period: baseline (before immersion in dentifrice slurry) and final (after treatment).

According to the values obtained, each group was exposed to a different type of
ARRUDA AM BRISO ALF OLIVEIRA JÚNIOR OB SANTOS PH TOSTI SC

MICROHARDNESS OF THE ENAMEL EXPOSED TO WHITENING DENTIFRICES
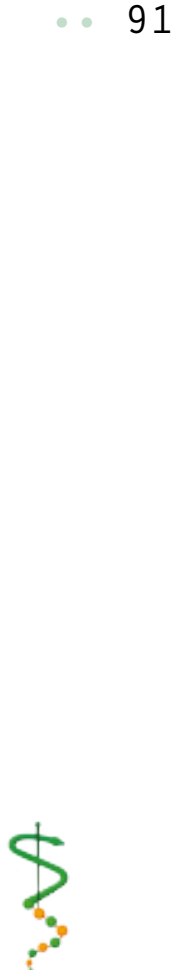

REV, ODONTOL.

UNIV, CID, SÃO PAULO

2012; 24(2): $90-5$, MAI 0 - AGO 


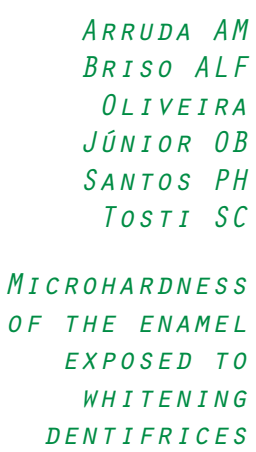

92

REV, ODONTOL.

UNIV. CID. SÃO

PAULO

2012; 24(2): $90-5$, MAI O- AGO :

Table 1. List of experimental groups according to the characteristics of each product, brand names, manufacturers and ingredients.

\begin{tabular}{|c|c|c|c|c|}
\hline Groups & Dentifrice type & $\begin{array}{c}\text { Dentifrice } \\
\text { brand name }\end{array}$ & Manufacturer & Ingredients \\
\hline I & $\begin{array}{l}\text { Silica-based } \\
\text { dentifrice }\end{array}$ & Colgate & $\begin{array}{l}\text { Colgate-Palmoli- } \\
\text { ve Company }\end{array}$ & $\begin{array}{l}\text { Calcium carbonate, Wa- } \\
\text { ter, Sorbitol, Sodium Lauryl } \\
\text { Sulfate, Sodium Monofluoro- } \\
\text { phosphate, Flavour, Cellulose } \\
\text { Gum, Tetrasodium Pyrophos- } \\
\text { phate, Methylparaben and } \\
\text { Sodium Silicate }\end{array}$ \\
\hline II & $\begin{array}{c}\text { Hydrogen } \\
\text { peroxide-ba- } \\
\text { sed dentifrice }\end{array}$ & $\begin{array}{l}\text { Colgate } \\
\text { Simply White } \\
\text { Toothpaste }\end{array}$ & $\begin{array}{l}\text { Colgate-Palmoli- } \\
\text { ve Co. }\end{array}$ & $\begin{array}{l}\text { Glycerin, hydrated Silica, } \\
\text { PEG-12, Sodium Lauryl } \\
\text { Sulfate, Flavor, Hydrogen } \\
\text { Peroxide, Sodium Hydroxide, } \\
\text { Cellulose, Sodium Saccha- } \\
\text { rin, EDTA, Propylparaben, } \\
\text { Tetrasodium Pyrophosphate, } \\
\text { Titanium Dioxide. }\end{array}$ \\
\hline III & $\begin{array}{c}\text { Carbamide } \\
\text { peroxide-ba- } \\
\text { sed dentifrice }\end{array}$ & $\begin{array}{l}\text { Rembrandt } \\
\text { Plus }^{\mathrm{TM}}\end{array}$ & $\begin{array}{c}\text { Gilette Com- } \\
\text { pany, Boston, } \\
\text { MA, USA }\end{array}$ & $\begin{array}{l}\text { Sodium Monofluorophospha- } \\
\text { te, Glycerin, Silicon, Car- } \\
\text { bamide Peroxide, Alumina, } \\
\text { Acidulated Amylopectin, Fla- } \\
\text { vor, Sodium Citrate, Papain, } \\
\text { Sodium Saccharin, Sodium } \\
\text { Lauryl Sulfate and EDTA }\end{array}$ \\
\hline IV & Artificial saliva & - & $\begin{array}{c}\text { Aphoticario } \\
\text { Manipulation } \\
\text { Pharmacy, SP, } \\
\text { Brazil }\end{array}$ & $\begin{array}{c}1.5 \mathrm{mmol} / \mathrm{l} \mathrm{Ca} 50 \mathrm{mmol} / \mathrm{KCl} \\
0.9 \mathrm{mmol} / \mathrm{I} \mathrm{PO} 4 \\
20 \mathrm{mmol} / \mathrm{l} \text { TRIS (tri-hydro- } \\
\text { xymethyl-aminomethane) } \\
\text { buffer, } \mathrm{pH} 7.0\end{array}$ \\
\hline
\end{tabular}

treatment. Dentifrices were applied in the form of oral suspension, obtained by mixing them with distilled water in the weight proportion of $1: 2$, using $18 \mathrm{ml}$ distilled water to $9 \mathrm{~g}$ dentifrice (da Silva et al. ${ }^{17}$, 2007). After treatment accomplishment, the $\mathrm{pH}$ of toothpaste samples were measured using the pHmeter Analyser (2A14-KA, São Paulo, SP, Brazil). For this purpose, suspension samples were obtained in a proportion of $1: 2$ and three measurements in each dentifrice sample were performed in a 10-minute interval between them, so that the $\mathrm{pH}$ was confirmed.

The fragments were in contact with the suspension for 15 minutes daily, simulating the time spent in 3 brushings. Following, the fragments were washed in tap water and stored in artificial saliva at 37 oC. This procedure was repeated for 21 days and during this period of time, group IV specimens remained in artificial saliva.
Next, specimens were cleaned with distilled water in an ultrasonic cleaner (BRANSON 2210, Danbury Connecticut, USA) for 10 minutes, dried and submitted to a second knoop microhardness analysis.

The results obtained were submitted to Kolmorogov-Smirnov normality test and analysis of variance (ANOVA) followed by Fisher's PLSD (Protected least significance difference) post test at 5\% significance level.

\section{RESULTS}

ANOVA test was applied to the microhardness values and significant difference was detected among treatments $(p<0.0001)$. Table 2 shows means and standard deviation of the enamel microhardness obtained after immersion in saliva (control) or in conventional dentifrice slurries, containing hydrogen peroxide $(\mathrm{HP})$ or carbamide peroxide $(\mathrm{CP})$. The 
mean obtained for the specimens before the immersion (baseline) was 232.4 (5.1). Fisher's Test showed that the use of any of the studied dentifrices caused significant reduction in the microhardness values $(p<0.001)$. It was also verified that the groups which received carbamide or hydrogen peroxide dentifrices showed similar microhardness results $(p=0.41)$ and these groups had higher reduction of microhardness than the group treated with conventional dentifrice $(p<0.0001)$.

\section{I SCUSS I ON}

At present, abrasive-rich dentifrices or the ones containing bleaching agents can be easily acquired and used by patients who want to get whiter teeth at a lower cost, even knowing that these products offer less intense whitening than in-office or at-home techniques (Perdigao et al. 18, 1998). Although dentifrices used daily remain in contact with the teeth for a short period of time, it has been reported that their frequent use may decrease the abrasion resistance of the enamel (Perdigao et al. ${ }^{18}, 1998$, Kakar et al. ${ }^{19}$, 2004). In this study, the immersion in dentifrice slurries caused a decrease of the enamel microhardness. On the other hand, enamel samples treated with artificial saliva alone (control group) preserved their hardness, showing values similar to the baseline.

Regarding the conventional dentifrice, the hardness decrease is possibly associated with the acid $\mathrm{pH}$ which varied between 5.2 and 5.4, inferior to the critical pH (5.5) for dissolution of enamel (Titley et al. 20, 1993). This fact is indirectly minimized through in vivo remineralization by

Table 2. Mean values, standard deviation and statistical analysis (ANOVA and Fisher's test) of the microhardness measurements after immersion in slurry.

\begin{tabular}{ccc}
\hline Groups & Means (SD) & $\begin{array}{c}\text { Statistical } \\
\text { decision* }\end{array}$ \\
\hline Control & $230.1(9.3)$ & $\mathrm{A}$ \\
Conventional & $125.2(11.9)$ & $\mathrm{B}$ \\
$\mathrm{HP}$ & $106.8(12.7)$ & $\mathrm{C}$ \\
$\mathrm{CP}$ & $103.2(12.8)$ & $\mathrm{C}$ \\
\hline \hline
\end{tabular}

*Similar letters represent statistical equality deposition of calcium fluoride, this fact is indirectly minimized through remineralization in vivo by the deposition of crystals of calcium fluoride from the saliva, which despite being a weak link can auxiliary to reduce the commitment of the surface microhardness structure (Casals et al. ${ }^{2}$, 2007, Dawes e Kubieniec ${ }^{21}$, 2004, Dodds et al.22, 2005).

In relation to whitening dentifrices, besides the influence of the acid $\mathrm{pH}$, it is believed that the notable decrease of the enamel microhardness may be associated with the action of oxygen free radicals, present both in hydrogen and carbamide peroxides, which may react with organic structures of the dental tissues (da Silva et al. ${ }^{17}, 2007$, Lima et al.. $\left.{ }^{23}, 2008\right)$. It is worth highlighting that the concentration of hydrogen peroxide found in the Colgate Simply White is $1 \%$, while the Rembrant Plus dentifrice shows $3 \%$ of carbamide peroxide. This last peroxide, when in contact with the dental tissues, decomposes into hydrogen peroxide at approximately $1 \%$, that is, same concentration of hydrogen peroxide as in the first dentifrice (Antonini et al. $\left.{ }^{24}, 2007\right)$.

Another factor which should be taken into account in the formulation of carbamide peroxide-based dentifrices is the presence of sodium citrate, a chelating salt which may react with the calcium present in the enamel and dentin (Ong e Strahan ${ }^{25}$, 1989). This reaction results in calcium-citrate complex, which causes mineral loss and microhardness decrease (da Silva et al. ${ }^{17}, 2007$, Perdigao et al. ${ }^{18}$, 1998). Moreover, the presence of urea may contribute to the denaturation of proteins existing in the spaces interprismatic, contributing to the occurrence of microstructural damage (Perdigao et al. ${ }^{18}, 1998$, Lima et al. ${ }^{23}$, 2008).

The EDTA present in the composition of both dentifrices containing peroxide, may also be considered a potential factor in enamel microhardness loss, since this product, when present in high concentrations, acts in dental demineralization. The $17 \%$ EDTA is the one responsible for the chelation of calcium ions in enamel structure. Besides the EDTA, the papain, present in the toothpaste Rembrandt Plus ${ }^{\mathrm{TM}}$
ARRUDA AM BRISO ALF OLIVEIRA JÚNIOR OB SANTOS PH TOSTI SC

MICROHARDNESS OF THE ENAMEL EXPOSED TO WHITENING DENTIFRICES

REV, ODONTOL. UnIV. CID. São PAULO 2012; 24(2): $90-5$, MA I 0 - AG 0 
ARRUDA AM :

BRISO ALF

OLIVEIRA

JUNIOR OB

SANTOS PH

TOSTI SC

MICROHARDNESS

OF THE ENAMEL

EXPOSED TO

WHITENING

DENTIFRICES

94

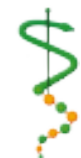

REV. ODONTOL.

UNIV, CID . SÃO:

PAULO

$2012 ; 24(2): 90-5$,

MAI O-AGO
ISSN 1983-5183

composition may also have influenced the results, once it acts as a chemical debridement in the chemo mechanical methods of caries removal, while it promotes the removal of protein content by "breaking" collagen molecules (Correa et al. ${ }^{3}, 2007$, Piva et al. ${ }^{26}, 2008$, Niu et al. ${ }^{27}, 2002$ ).

Consequently, the null hypothesis must be rejected as dentifrices containing bleaching agents affected the enamel microhardness. Despite the reduced period of time (21 days), and the fact that the in vitro investigation limit the study, it can be stated that peroxide-based dentifrices affected the enamel microhardness, and, thus, further longitudinal studies are needed to understand the action of these agents over

time (Sasaki et al. $\left.{ }^{9}, 2007\right)$, as well as in situ and clinical studies to analyze the behavior of these dentifrices in the oral environment.

The present in vitro study demonstrated that carbamide- and hydrogen peroxide-based dentifrices, as well as a conventional silica-based dentifrice decreased the superficial microhardness of the bovine enamel. The most significant decrease was observed following peroxide-based dentifrices treatment.

\section{ACKNOWLEDGMENTS}

This investigation was supported by Fapesp 09/51273-1

\section{REFERENCES}

1. Hegedus C, Bistey T, Flora-Nagy E, Keszthelyi G, Jenei A. An atomic force microscopy study on the effect of bleaching agents on enamel surface. J Dent 1999 Sep;27(7):509-15.

2. Casals E, Boukpessi T, McQueen CM, Eversole SL, Faller RV. Anticaries potential of commercial dentifrices as determined by fluoridation and remineralization efficiency. J Contemp Dent Pract 2007 8(7):1-10.

3. Correa FN, Rocha Rde O, Rodrigues Filho LE, Muench A, Rodrigues CR. Chemical versus conventional caries removal techniques in primary teeth: a microhardness study. J Clin Pediatr Dent 2007 Spring;31(3):187-92.

4. Croll TP. Enamel microabrasion followed by dental bleaching: case reports. Quintessence Int 1992 May;23(5):317-21.

5. Gerlach RW, Ramsey LL, White DJ. Extrinsic stain removal with a sodium hexametaphosphate-containing dentifrice: comparisons to marketed controls. J Clin Dent 2002 13(1):10-4.

6. Haywood VB, Leonard RH, Nelson CF, Brunson WD. Effectiveness, side effects and long-term status of nightguard vital bleaching. JAm Dent Assoc 1994 Sep;125(9):121926.

7. Gerlach RW, Liu H, Prater ME, Ramsey LL, White DJ. Removal of extrinsic stain using a $7.0 \%$ sodium hexametaphosphate dentifrice: a randomized clinical trial. $J$ Clin Dent 2002 13(1):6-9.

8. Crews KM, Duncan D, Lentz D, Gordy FM, Tolbert B. Effect of bleaching agents on chemical composition of enamel. Miss Dent Assoc J 1997 Spring;53(1):20-1.

9. Sasaki RT, Barbosa MC, Florio FM, Basting RT. Enamel microhardness and shear bond strength after treatment with an $18 \%$ carbamide peroxide bleaching varnish. Am J Dent 2007 Oct;20(5):324-8.

10. Haywood VB. History, safety, and effectiveness of current bleaching techniques and applications of the nightguard vital bleaching technique. Quintessence Int 1992 Jul;23(7):471-88.

11. Howard WR. Patient-applied tooth whiteners. J Am Dent Assoc 1992 Feb;123(2):5760. 
12. Ernst CP, Marroquin BB, Willershausen-Zonnchen B. Effects of hydrogen peroxide-containing bleaching agents on the morphology of human enamel. Quintessence Int 1996 Jan;27(1):53-6.

13. Garcia-Godoy F, Villalta P, Bartizek RD, Barker ML, Biesbrock AR. Tooth whitening effects of an experimental power whitening toothbrush relative to an $8.7 \%$ hydrogen peroxide paint-on gel control. Am J Dent 2004 Jan;17 Spec No(25A-30A.

14. White DJ. Development of an improved whitening dentifrice based upon "stain-specific soft silica" technology. J Clin Dent 2001 12(2):25-9.

15. Mankodi S, Sowinski J, Davies R, Ellwood R, Bradshaw B, Petrone ME, et al. A six-week clinical efficacy study of a tooth whitening tartar control dentifrice for the removal of extrinsic tooth stain. J Clin Dent 1999 10(3 Spec No):99-102.

16. Faraoni-Romano JJ, Turssi CP, Serra MC. Concentration-dependent effect of bleaching agents on microhardness and roughness of enamel and dentin. Am J Dent 2007 Feb;20(1):31-4.

17. da Silva BM, Florio FM, Basting RT. Shear bond strength of resin composite to enamel and dentin submitted to a carbamide peroxide dentifrice. Am J Dent 2007 Oct;20(5):319-23.

18. Perdigao J, Francci C, Swift EJ, Jr., Ambrose WW, Lopes M. Ultra-morphological study of the interaction of dental adhesives with carbamide peroxide-bleached enamel. Am J Dent 1998 Dec;11(6):291-301.

19. Kakar A, Rustogi K, Zhang YP, Petrone ME, DeVizio W, Proskin HM. A clinical investigation of the tooth whitening efficacy of a new hydrogen peroxide-containing dentifrice. J Clin Dent 2004 15(2):41-5.

20. Titley KC, Torneck CD, Ruse ND, Krmec D. Adhesion of a resin composite to bleached and unbleached human enamel. J Endod 1993 Mar;19(3):112-5.

21. Dawes C, Kubieniec K. The effects of prolonged gum chewing on salivary flow rate and composition. Arch Oral Biol 2004 Aug;49(8):665-9.

22. Dodds MW, Johnson DA, Yeh CK. Health benefits of saliva: a review. J Dent 2005 Mar;33(3):223-33.

23. Lima DA, Silva AL, Aguiar FH, Liporoni PC, Munin E, Ambrosano GM, et al. In vitro assessment of the effectiveness of whitening dentifrices for the removal of extrinsic tooth stains. Braz Oral Res 2008 Apr-Jun;22(2):106-11.

24. Antonini B, Dos Santos C, Veloso K. Effect of toothbrushing with whitening toothpaste on surface roughness of enamel and dentin. Rev Odontol UNESP 2007 36(2):12126.

25. Ong G, Strahan JD. Effect of a desensitizing dentifrice on dentinal hypersensitivity. Endod Dent Traumatol 1989 Oct;5(5):213-8.

26. Piva E, Ogliari FA, Moraes RR, Cora F, Henn S, Correr-Sobrinho L. Papain-based gel for biochemical caries removal: influence on microtensile bond strength to dentin. Braz Oral Res 2008 Oct-Dec;22(4):364-70.

27. Niu W, Yoshioka T, Kobayashi C, Suda H. A scanning electron microscopic study of dentinal erosion by final irrigation with EDTA and $\mathrm{NaOCl}$ solutions. Int Endod J 2002 Nov;35(11):934-9.

Recebido em: 20/01/2012

Aceito em: 09/04/2012 